This is an electronic reprint of the original article. This reprint may differ from the original in pagination and typographic detail.

Author(s): Perälä-Littunen, Satu

Title: $\quad$ Childcare and work : exploring the views of Finnish mothers and fathers

Year: $\quad 2018$

Version:

Please cite the original version:

Perälä-Littunen, S. (2018). Childcare and work : exploring the views of Finnish mothers and fathers. Community, Work and Family, 21(2), 209-225. https://doi.org/10.1080/13668803.2016.1274289

All material supplied via JYX is protected by copyright and other intellectual property rights, and duplication or sale of all or part of any of the repository collections is not permitted, except that material may be duplicated by you for your research use or educational purposes in electronic or print form. You must obtain permission for any other use. Electronic or print copies may not be offered, whether for sale or otherwise to anyone who is not an authorised user. 
Satu Perälä-Littunen

\section{Childcare and work - exploring the views of Finnish mothers and fathers}

\section{Introduction}

Finding a balance between work and childcare is one of the challenges faced by parents. In previous literature, childcare and work are described mainly as being either 'enemies' or 'allies' (e.g., Greenhaus \& Powell, 2006). For example, the literature suggests that the workfamily conflict is experienced when the demands of work interfere with participation in the family role, and vice versa (Greenhaus \& Beutell, 1985). Combining family life, childcare, and work is often seen as requiring reconciliation, and is even perceived to be the reason for workplace production deviance (Ferguson, Carlson, Hunter, \& Whitten, 2012), or at least as a factor having a negative impact on career development (Westring \& Ryan, 2011). However, work is not always the stressor. Hochschild (2001) noted that sometimes the care of young dependent children is seen as demanding and stressful work. Parents even try to escape from childcare; for instance, by working longer hours than is expected of them.

Because parenting is still highly gendered, it has been suggested that more attention should be paid to gender in research focusing on the reconciliation of work and childcare (Greenhaus \& Powell, 2006). Within the European framework, fathers face new challenges when the expectations of men to be active fathers clash with the reality of an insecure and highly competitive work market, in which time spent at work is regarded as an indicator of work commitment (e.g., Hobson \& Fahlén, 2009). Lack of time in general is one of the areas where working parents face challenges. For example, it has been noted to be a factor in producing feelings of guilt in mothers (Guendouzi, 2006).

Although it is evident that childcare often is actualized as gendered (e.g., Ciccia \& Bleijenbergh, 2014), there are mothers and fathers who think and act with disregard for 
gendered expectations. For example, there are fathers 'speaking in the language of care' in the same way as is expected of mothers (Doucet, 2006, p. 5).

All that we call 'work' is not similar, nor is the meaning of work the same to everyone. Employees find meaning in their work in varied ways, and work has different meanings to different people. (Super \& Sverko, 1995; Wrzesniewski \& Dutton, 2001). Likewise, work orientations differ. Literature on work orientation suggests that people can have three different types of orientation. Individuals can see their work as a job and focus on the material benefits of work. Work can also be a career, and the most significant part of working consists of the rewards brought about by promotions in the organizational or occupational structure of work. For some individuals, work is a calling and work is an end in itself. (Rosso, Dekas, \& Wrzesniewski, 2010).

Care as a social activity or as a concept has been addressed by many scholars since the 1970's, when it no longer was considered as a 'taken-for-granted' feature in female lives (e.g., Moss \& Brannen, 2003; Saraceno, 2008). Care has been given various definitions, and the borderline between what is considered "work' and what is "care' is not clear (e.g., Guest, 2002). Feminist scholars in particular have focused on care and work, considering their similarities and differences (e.g., Lynch, 2007). Discussions have circled around paid care, care as a profession, unpaid care, care as labor of love, and care as a duty, to name a few of the many issues (see Bowlby, MacKie, Gregory, \& MacPherson, 2010).

Parenting policies in Finland, like in other Nordic countries, promote working motherhood and caring fatherhood, thus furthering gender equality (Ellingsæter \& Leira, 2006). For instance, Finland has never had a strong housewife culture due to the fact that the wages of both parents were needed to support the family (see Nätkin, 1997). Investing in public childcare services offers parents various means of financial support so that they may stay at home and take care of their children (e.g., Sümer, 2009). For instance, parents have the 
right to care leave until the child reaches the age of three years (Mahon, Anttonen, Bergqvist, Brennan, \& Hobson, 2012). During this time, parents are entitled to a paid child homecare allowance, and in many cases one of the parents stays at home (Haataja \& Nyberg, 2006). The state-paid compensation for a parent on parental leave is income related, and at the time when data for this study were gathered it was about $70 \%$ of average income (Lammi-Taskula, 2007). Parents can share a period of parental leave. However, despite the shared understanding of the importance of the father's participation in childcare and the mother's right to paid work in Nordic countries, the actualization of statutory parental leave is gendered; parental leave is mainly taken by mothers (Johansson \& Klinth, 2007; LammiTaskula, 2007). Nevertheless, most mothers plan to return to work at some point in their lives (Salmi, Lammi-Taskula, \& Närvi, 2009).

The ideology of gender equality and the ideal of parental choice (Närvi, 2012) make the Finnish context interesting. It is thus in this context, with well-developed public day-care facilities and parental benefits for a parent who stays home to take care of the children, that the question of whether to work or stay home is understood, more than ever, as being a question of parental choice (Ellingsaeter \& Leira, 2006). The state gives the parents a choice, but on what grounds do they choose? Närvi (2012) suggests that individual preferences and each spouse's relative position in the labor market play a role in the decision-making.

In this study, meanings given to childcare and work by working parents and stay-athome parents are explored. Meanings, ideas and beliefs are here understood to be part of parents' cultural belief system (see e.g., Harkness \& Super, 1996) The aim is to shed light on what factors parents consider when they decide who is going to stay at home.

\section{Data and method}

This is a qualitative study and the meanings parents give to childcare and work are studied as socially constructed (see e.g., Gubrium \& Holstein, 1990). The data consist of thematic 
interviews with two working mothers, two mothers on parental leave, and four fathers who were or had been on parental leave. Using snowball sampling, the parents on parental leave were reached via child healthcare centers and the working mothers and fathers were contacted through their places of work. One of the criteria for choosing the parents was that they had to have at least one relatively young child, preferably under the age of three. In Finland, state support guides parents to opt for homecare as long as the child is less than three years old. Thus, all interviewed parents, except Teija, had a child or children under the age of three years. Moreover, the parents on leave had to have made a decision to stay at home, and had not been or were not at home 'against their will', for example, because of unemployment.

The table below summarizes the information concerning the interviewed. Pseudonyms are employed to protect the confidentiality of the interviewed parents.

Table 1. The interviewed parents

\begin{tabular}{|c|c|c|c|}
\hline $\begin{array}{l}\text { Name } \\
\text { (gender) } \\
\text { and age }\end{array}$ & $\begin{array}{l}\text { Family: spouse ( his/her profession), children } \\
\text { (age) }\end{array}$ & $\begin{array}{l}\text { Educational } \\
\text { background or } \\
\text { profession }\end{array}$ & Time at home \\
\hline $\begin{array}{l}\text { Anna }(F), \\
23 \text { years }\end{array}$ & $\begin{array}{l}\text { Husband,(office worker), daughter (2years) and } \\
\text { daughter (12months) }\end{array}$ & Office worker & 1 year and 8 months \\
\hline $\begin{array}{l}\text { Teija }(\mathrm{F}), 35 \\
\text { years }\end{array}$ & $\begin{array}{l}\text { Husband (no information), daughter ( } 6 \text { years } \\
\text { and daughter ( } 5 \text { years) }\end{array}$ & Office worker & 2 years \\
\hline $\begin{array}{l}\text { Kati }(F), 30 \\
\text { years }\end{array}$ & $\begin{array}{l}\text { Husband (university student and a part-time disc } \\
\text { jockey), son (6 months) }\end{array}$ & Academic degree & $\begin{array}{l}\text { Presently a stay-at-home } \\
\text { mother for } 6 \text { months }\end{array}$ \\
\hline $\begin{array}{l}\text { Maija }(\mathrm{F}) \text {, } \\
28 \text { years }\end{array}$ & $\begin{array}{l}\text { Husband (entrepreneur), daughter ( } 3 \text { years) and } \\
\text { son ( } 3 \text { months) }\end{array}$ & Academic degree & $\begin{array}{l}\text { Presently a stay-at-home } \\
\text { mother for } 3 \text { years }\end{array}$ \\
\hline $\begin{array}{l}\text { Pekka }(\mathrm{M}), \\
33 \text { years }\end{array}$ & $\begin{array}{l}\text { Wife ( academic degree in economics, worked } \\
\text { as a teacher),daughter ( } 16 \text { months) }\end{array}$ & Military officer & $\begin{array}{l}3 \text { months alone and } 1 \text { months } \\
\text { together with his wife }\end{array}$ \\
\hline $\begin{array}{l}\text { Esa }(\mathrm{M}), 40 \\
\text { years }\end{array}$ & $\begin{array}{l}\text { Wife (teacher), son (6 years) and daughter ( } 3 \\
\text { years) }\end{array}$ & $\begin{array}{l}\text { Computer } \\
\text { numeric } \\
\text { controlled }(\mathrm{CNC}) \\
\text { machinist }\end{array}$ & $\begin{array}{l}\text { For each child until the child } \\
\text { was } 12 \text { months }\end{array}$ \\
\hline $\begin{array}{l}\text { Kai }(M), 38 \\
\text { years }\end{array}$ & $\begin{array}{l}\text { Wife (university degree), son (2 years) and son } \\
\text { (12 months) }\end{array}$ & $\begin{array}{l}\text { Degree in } \\
\text { economics } \\
\text { worked as an } \\
\text { executive in an } \\
\text { accounting firm }\end{array}$ & $\begin{array}{l}\text { With the older son } 4 \text { months } \\
\text { and three weeks with both of } \\
\text { his sons }\end{array}$ \\
\hline $\begin{array}{l}\text { Pete }(\mathrm{M}), 38 \\
\text { years }\end{array}$ & $\begin{array}{l}\text { Wife (teacher), son (12 years), daughter ( } 10 \\
\text { years), son ( } 7 \text { years) and daughter ( } 12 \text { months) }\end{array}$ & Warehouseman & $\begin{array}{l}\text { For each child from the age of } \\
10 \text { months to the age of } 18 \\
\text { months }\end{array}$ \\
\hline
\end{tabular}

All parents were asked to talk about the following topics: the reasons why they chose to stay at home or start to work; whether the decision was easy to make; whether the decision 
was the right one; with whom they discussed the issue; whether their way was the most usual and perhaps the most accepted way culturally to act; what work/caring means to them; whether there are different ways of caring (due to a person's personality, gender, age, etc.); how they feel about being a parent; how had becoming a parent changed them; where they thought they had learned to care; and what they perceived as the effects that staying at home/working had on their children, spouse, and themselves. The order in which these topics were presented varied according to what each interviewed said and how the interviewer used follow up questions to elicit further descriptions. The topics were chosen based on previous literature on work-family reconciliation and parenting, including topics such as parents' working hours (e.g., Eby, Casper, Lockwood, Bordeaux, \& Brinley, 2005), fathers' involvement in childcare (e.g., Milkie, Bianchi, Mattingly, \& Robinson, 2002), children's safety (e.g., Forsberg \& Strandell, 2007), and participation in the family and work roles (Greenhaus \& Beutell, 1985). However, due to the nature of an exploratory study the researcher remained sensitive also to new topics which might come up in the interviews. The interviews were transcribed word for word, with each lasting from 30 minutes to one hour and 40 minutes. Altogether, there were seven hours and 30 minutes of recorded interviews and 140 pages of transcribed data. The mothers' interviews lasted for two hours and 40 minutes, while the fathers' interviews were longer and lasted for four hours and 55 minutes. The interview excerpts were translated from Finnish into English for the purpose of reporting the results to the international scientific community, but the analyses were done using the original Finnish transcripts.

The data were analyzed thematically applying an inductive bottom-up approach (Braun \& Clarke, 2006). In the analysis, both commonalities and differences were noted. The analysis began with a search for reappearing themes pertaining to childcare and the meanings of work; then the expressions of a certain theme (the theme's meanings) were summarized in one 
sentence, such as 'male friends' reactions.' The summarized sentences (themes that related to each other) were put together to form codes (see Gibson \& Brown, 2009), such as 'reactions from outside the family when the father stays at home.' Finally, the minor codes were organized under three major codes.

\section{Findings}

The three major codes 'Being a Parent,' 'The Child,' and 'Work,' form the main titles and the minor codes appear as subtitles under the main titles in the presentation below.

\section{Being a parent}

Stay-at-home parent now and working parent at some other point in life

When the parents were interviewed they were positioned as either working or stay-at-home, but none of the mothers intended to spend their entire life at home, taking care of children and a husband. Instead, the mothers stayed at home when their children were small and intended to return to work later. Likewise, none of the interviewed fathers had been at home for longer than one year. Thus, all of the parents were, had been, or intended to be both at work and at home. The parents had used family leaves, job alteration leave, and vacations, as well as saved money to enable the stay-at-home period.

The two stay-at-home mothers who were interviewed both identified themselves as stay-at-home mothers, and expressed their intention to start working later, or as Kati, who had the qualifications of a translator, said 'work a little while at home.' Maija, a stay-at-home mother, said that her decision to stay at home was not a 'conscious' one and that she, in fact, was planning to start working and had even gone to a job interview, although she described herself as lucky when she did not to get the job. However, she said that she did not know how long she was going to stay at home. 
Both working mothers had been at home when their children were babies. Teija had been at home for two years, but as she said: 'it was only because the girls were born so close after each other.' However, Anna did not seem to be so sure about working when children are small. She mentioned some of her friends who think that it is better for the children if the mother stays at home when the children are young. She said, 'I don't think of myself as a career woman either, and I had not previously thought that I would be working or studying when my children are young.' Anna knew that working for her was only temporary and would last only until the birth of a new baby because the religious beliefs of Anna's family did not allow the use of contraceptives. She said that she is happy to have a profession and to be able to have a job 'between' the children, and also in the future.

\section{Negotiations}

Previous research on the idea of parental choice in deciding which of the parents is going to stay at home or to start working suggests that parents are engaged in various negotiations while considering the choices they have (e.g., Närvi 2012). All interviewed parents except Teija talked about negotiations, or rather discussions, with significant others in their lives. Some of the parents had consulted their friends when making the decision. Maija had discussed the issue with her friends and had gotten an impression that starting to work would cause scheduling problems, and that she would not have time for the child.

For the fathers staying at home, caring for their children was a more conscious decision that required negotiations with the employer. For mothers, staying at home seemed easier, and neither of the working mothers mentioned negotiations with their respective employers.

The parents used various kinds of arrangements for the fathers to be able to stay at home with their children. Besides the parental or family leave, Esa had used his right for job alternation leave. The purpose of the job alternation leave is to support the employee's coping at work and offer a job for a fixed term for an unemployed person, thus reducing unemployment. 
Pete's employer did not agree with Pete's wish to take job alteration leave, so Pete took the family leave to which he was entitled. Both Kai and Pekka described the negotiations with their employer and the tactics they used to get what they wanted from their employers. Kai says:

Kai: well I started to talk about it long before the birth (pause) I mean that it took quite

S: your employer's attitude was positive?

Kai: well positive and kind of positive but well there yes it caused some problems I mean it was not so usual for men to take long leaves like that but what I did I did not ask for permission from the employer I mean I just told what I wanted (pause) but well (pause) I employed my tactics cause I knew what I wanted but I kind of negotiated with the employer

Most families had saved money to be able to afford the stay-at-home period. In Maija talked about family finance with her husband. Maija said: 'if he would have thought that we could not make it without my salary, I would have looked for a job and started to work.'

All interviewed except Teija had discussed the issue with their spouse. She said: 'I do not have to talk about it, for example, with my husband, he knows his opinion does not count, that I do what I want to do.' Quite differently from Teija, Anna said that she needed her husband's support before she could decide, otherwise, she would not have been able to make the decision. Esa had discussed staying at home with his wife, but in the end he made the decision. He said the arrangements were easier for him to make.

In some families the spouses also considered their personalities and talked about the meaning of work for each spouse; in Pekka's words, 'It is again a question of who is more ambitious in his/her work and interested in a career.' In addition, Pekka described his wife as a 'strong willed person.' In Pete's case, a factor affecting the decision was that his wife did not like to be at home. She missed the company of other adults, while Pete described himself as someone who liked to be left alone. Moreover, at least according to Pekka, gender was also a factor. When the interviewer asked Pekka about the negotiations, he brought up his belief 
that women change during the pregnancy. Before the baby was born, his wife was sure that she wanted to continue working, but after the birth she did not wish to leave the baby, so she stayed at home when their child was an infant.

According to Kai, his wife had no objections when he expressed his wish to stay at home. However, Kai said that he knew there were mothers who would not let the father stay at home with the baby. When talking about mothers of this kind, Kai's expressions such as talking about "monopoly" and the experience needed for a job, resembled language used in business world which was his working context. He said, 'It was something like that (break) that the father has not enough experience of that kind of task, or something like that.' Kai concluded 'that sometimes the mother wants to have a monopoly of childcare.' Kai emphasized the fact that their decision was good for both parents. He said, 'I got what I wanted. I was able to stay at home, and my wife was able to work.'

\section{Taking care of children at home - is it work?}

As mentioned previously, the status of the interviewed as either working or a stay-at-home turned out to be temporary. Likewise, the interviewed were asked if they considered taking care of children at home as work, reflecting the ideas presented in the literature concerning care as work or labor. According to two of the interviewed mothers-Maija, a stay-at-home mother and Anna, a working mother-taking care of children was work. Maija considers childcare as work and she says:

\footnotetext{
Maija: ... how would I say it... though this is work in a way ... the difference between leisure and work become blurred.

S: yeah yeah but would you say that taking care of your children is work even though you're not paid to do it?

Maija: Yes, in my opinion yes it is work
} 
Anna, a working mother, also said that taking care of your children at home was work because 'it is not easy and you can't do what you feel like doing all the time, you have to attend to the needs of the children...'

According to Esa and Pete, staying at home was not work. Esa pointed out that childcare and household work were only 'part of the everyday life'. Pete said that he was 'doing something' when he is taking care of the children, but that was not work.

\section{What is expected of a good parent?}

Parenting, especially mothering, is loaded with moral expectation that is often intertwined with cultural ideas of how a good parent should behave (see Hays, 1996). The interviewed parents were well aware of these expectations, which at least in the Finnish context produced contradictory demands for mothers. Maija talked about two different schools prescribing how you should act as a mother: 'I think that we have two different schools; that there are those who stay at home and who among themselves support the ideology of stay-at-home moms, but that the general opinion says that you should work.'

\section{Mothers feeling guilty}

Being the target of contradictory demands made the mothers feel guilty, regardless of whatever they did; if they stayed at home or if they started working. This suggests that childcare is considered a mother's responsibility. Not one of the fathers talked about feeling guilty when working or staying at home taking care of their children. Kati described her feelings and said that she was well-educated (she had a master's degree), so it was her duty to put her education to use later. Maija continued, after having mentioned 'the two schools of good mothering,' by pointing out that mothers themselves like to blame other mothers of bad mothering and that 'whatever you do you are bound to feel guilty.' Likewise, Anna talked 
about feeling guilty, although she was not so sure that the feeling is 'guilt' because she thought that working also made her a better mom when she was not with the children all day. Anna and Maija also pointed out that the lack of time was a problem when trying to balance work and childcare, and that this was a factor causing feelings of guilt.

\section{Who is the 'Number One' parent?}

For two of the fathers, childcare seemed to have the same kind of meanings as work had for them. They saw it as an arena for competing. They talked about competition and of the need to show that they can do it when talking about childcare. Pekka said, 'Perhaps I got a kind of need to show that I can do it, that the home, that everything is ok at home all the time and that food is ready when the wife comes home from work.' Kai was not happy with 'trivial tasks' and the role of 'a kind of assistant' that he was given at home, and that he wanted to show that he was capable of more, even though he 'had not been with children a lot before.' Mothers did not seem to be aware of the competition; at least they do not talk about it.

In a previous study it was noted that Finnish parents produced ambivalent descriptions of good parents, and that they were uneasy about giving separate descriptions for mothers and fathers. Yet there seemed to be a strong belief in the primacy of the mother (Perälä-Littunen, 2007). Likewise, the interviewed fathers were eager to point out that the mother is still the primary parent, even if the father stayed at home, thus supporting the belief of the primacy of the mother.

One of the advantages of mothers over fathers, according to the fathers, was the fact that mothers breastfeed. Esa explained that a father could never replace a mother because the relationship between the mother and the child was so special. Kai agreed with Esa and, like Esa, pointed out that breastfeeding was the reason for the special quality of the relationship. 
According to Pekka it would even be very difficult for the mother to break that bond between herself and the child.

Pekka: but I believe that breastfeeding for instance is one factor which makes the child and the mother very close to each other and that is impossible for the father to reach ever

$\mathrm{S}: \mathrm{mm}$

Pekka: unless the mother really screws it up

S: yeah

Pekka: but the bond between the mother and child is so strong that the mother must be really weird to be able to destroy that bond

$\mathrm{S}: \mathrm{mm}$

Pekka: break that ... but on the other hand you really cannot compete

\section{Reactions from outside the family when the father stays at home}

In general the fathers said that their decision to stay at home and take care of the children was supported by their female relatives and colleagues. Male friends and work mates had likewise been supportive, but to some extent there seems to be slight suspicion relating to the masculinity of the stay-at-home father. Pete described his experience of attending a music play school and said, 'now that we (Pete and the child) started attending a music playschool, well, I have been laughing because of it (laughs), that I just sing and play with the others there (laughs).' According to Pete, his mates, however, had been supportive. He said, 'But no, I mean, no wondering on behalf of my mates, that what on earth you think you are doing.' Pete talked about the support he had received, but at the same time he was laughing. The laughter can be interpreted to suggest that Pete did not feel completely comfortable at the music playschool in his role of a stay-at-home father. Thus even though his male friends were positive, he himself was not completely sure of his role.

Esa told a slightly different story. His friends seemed to be wondering and suspecting that Esa as a stay-at-home father had something else, and not just childcare, on his mind, such 
as more masculine activities like building a house. Esa said that '...quite many said that "What are you going to do during the year?" Although they knew that I have one-year-old at home, but quite many asked "Are you going to travel or build a house or something?"

\section{The child}

All interviewed parents talked much about the importance of the child and how the wish to be with the child pulled them home. The talk about the child was very emotional, up to the point that some of the parents apologized for being so emotional and attached to their child.

\section{Meanings connected to the child and having a family}

According to the interviewed parents, the birth of the child brought along changes, and the parents were surprised by their own reactions. The order of importance in life changed, thus sometimes changing what the parents previously thought to be the best for them. Maija answered to the question of how she felt about being a mother, 'Eh, this may sound a bit of a cliché, but it is like, eh, it gives you a new meaning, I mean completely for your life.' Kati discussed the change in the way she thought about work before the child was born. She pointed out that her needs had changed and said, 'I do not want to start working now, even though I thought before that I would want to (break) at least not yet.'

Also the fathers talked about changes brought to their lives when the child was born. Kai said that the birth of the child changed the order of priorities in his life. Kai continued, and talked about his wish to have an active part in his child's life. He said, 'Well, I had, I had a strong desire to be at home for a while. It was, of course, the fact that I had become a father -- I wanted all of it.' 
Pekka, who was a professional soldier, talked about the meanings that family and becoming a father brought to his work. He saw himself as a protector of the family, and thus even the meaning of his work changed when he became a father.

Pekka: really I think that it (the birth of the child) has had an enormous influence I mean eh also professionally and then the meaning of my work changed eh I also realized certain things (Pause) things (Pause) in connection to my work why things have been organized the way they were and why because the child is all of a sudden something I mean has a lot more meanings than when you were alone or with your spouse.

\section{Loving the child}

Parents described love for the child as one of the factors pulling them home. Several parents talked long about their feelings towards their child, and used the word "love' when describing the feeling. Pekka emphasized the special nature of loving the child. He said that the love for your child is different from the love for your spouse. He summarized the special quality of parents' love for the child by the word 'irreversible.' According to Pekka, "the bond between you and the child, those emotions, are quite different; the sacrifices you are willing to do for your child, they are, must be, endless.'

Likewise, Maija talked about how she did not want to leave the baby, not even to spend some time on her own, because she was "still so in love with the baby.' Maija described her feelings of being a mother: 'It feels wonderful and happy and perfect, that's how I feel.' However, happiness was not the only emotion connected to motherhood for Kati. She said it was 'perhaps also a bit agonizing, because you know all the time that the child will not be a small child forever and that he is going to leave you one day.' Kati had applied for a job, but when she was thinking about starting to work, she realized that she did not want to give up the time she was able to be together with the baby. She said that she even cried over the thought 
that she might have to leave the baby. Later, she talked about her close relationship with the baby, and used the words 'pleasurable symbiosis'.

\section{Rewards, feedback, and making sacrifices}

In the previous section, Kati said that her close relationship with the child gave her pleasure. Other parents also talked about getting feedback on what they were doing. For Anna, one of the meanings of work was that her work and effort were noticed, and that what she did made a difference. She compared working to childcare, and realized that she felt nobody, not even she, valued the things she did at home.

Kai had a quite contrary view. For him, taking care of the child was more rewarding, and he talked about 'immediate feedback.' He said, 'When you feed the child or change the nappies, you see that the child is happy.' Kai continued to compare work and childcare, and said, 'When you are working, I mean, nobody is so satisfied in what you have done.'

In the interviews, the parents were asked if they felt they had sacrificed something when they stayed at home to take care of their child. Maija said that, in her opinion, it was not a sacrifice to take care of one's own children. She talked about the values of life that she had, and that she regarded her children and family as the most important things in her life, so it was not a sacrifice if she postponed starting her career. Later on, the interviewer asked Kati if she thought she was making a sacrifice when she stayed at home. Kati answered, 'Well, I don't feel that I'm sacrificing anything. Earlier I thought that I might feel or think like that, but at the moment at least I am getting much more out of being a mother than I could think of, I mean I am not making any sacrifices.'

According to Anna, however, the mother must sometimes make sacrifices and put the needs of the child before her own needs. She said, 'But I would say that the mother sacrifices; 
that you must take care of your children even when you are tired or when you would rather do something else.'

\section{Wishing to have more time to spend with the child}

Both mothers and fathers talked about time and their wish to spend more time with the child. Pekka described his normal week and said that he came home at about six, which meant that he had only a few hours to spend with the child before she needed to go to bed. Pete talked about the same problem when he explained why he had stayed at home. He said that, on the one hand, he wanted to be with his children and on the other hand he did not like his work, especially, nor did he like to work late and be too tired to be with his children. For Maija, the issue of time meant 'scheduling everything and finding the time, and the feeling that you do not have enough time for the child.'

\section{Day care vs homecare - which is better for the child?}

Both Pete and Esa talked about homecare as the best solution for a small child. Esa stayed at home when their son was 12 months old and his wife started working again. He said 'he was so small,' and both parents were happy when they did not have to take the child to day care. Kati had a firm belief that a child should be cared for at home until the age of three. However, she did not say that the career should necessarily be the mother. Who took care of the child was not as important as the place where the child was cared. Pekka agreed with Kati. In Pekka's family, childcare when both parents were working was organized so that Pekka's mother came to their house to take care of the child. Thus the place, home, was seen as more important than the fact of who was taking care of the child.

All other parents, except Teija, thought that home was the best place for a small child. Teija had a very firm opinion that it was better for the child to be at daycare. She saw social 
contacts as very important for both herself and her daughters. She said, 'Well, I think that children need to be in a social environment, and that there are other children, their friends.' Teija continued by describing how her daughter Sylvi was in family care earlier and was very timid at that time, but now, when she goes to a daycare, she is much braver.

Interestingly, Teija and Maija seemed to have completely different views on what kind of care was good for a timid child. According to Maija, her daughter became braver when she was cared for at home, while Teija concluded that her daughter overcame being timid as the result of being at daycare.

The interviewed Finnish parents did not directly talk about the quality of daycare, probably because in Finland it is assumed to be of high quality. However, they were not so sure of the effects of daycare on the child's development. Maija, for instance, talked about giving a good start for her child by taking care of him at home. She said, 'It is not the only way (that the mother stays at home) but, eh mm, I think I would get very strong feelings of guilt if I thought that I could have given a better start for my child and I had not used that opportunity.'

Kati had read baby and family magazines. 'I remember reading various articles reporting the expert views that it would be best for the child's development if he/she could be at homecare cared by the mother or a relative or a child minder.' She concluded that 'you should not take the child away from home.'

\section{The best for the child and for the parent}

The needs of the mother and the child are not necessarily contradictory. Both Maija and Kati regarded homecare as the best choice for both themselves and their children. Maija talked about a difficult period in her daughter's life, and said that '... somehow, she was so dependent on me that it was a good solution to stay at home.' 
Kati talked about dependency for a long time, and came to the conclusion that the child was dependent on her, but that she also was dependent on the child. She worried that her dependency might harm the child eventually, hindering the child's development.

Both stay-at-home mothers, Kati and Maija, pointed out that being at home fulfils their needs; not only the needs of their children. Kati said that she now had different needs than before, when the child was born. Maija said that being a mother had given her life a new meaning, and that she found mothering very satisfying.

The personality of the parent is something that needs to be taken into account when considering which of the parents is going to stay at home. For Pete's wife, going to work was the best choice, as she needed adult social contacts. Pete described the situation: '.. if she had to stay at home all day she would go crazy (laughs).' Pete said that he himself was 'less social, more like a hermit,' and that he enjoyed when 'it is quiet here.'

\section{Work}

None of the interviewed parents described themselves as career persons or talked about work ambitions. However, work appeared to be an important part of their lives. Some of the parents expressed meanings suggesting that work for them was a calling or an end in itself. Likewise, some of the parents talked about supporting their families financially when they were working, suggesting that work for them was a job.

\section{Work can push you home}

The interviewed fathers had not been satisfied with their jobs and working hours. Thus work was a factor pushing them home. However, the fathers did not see dissatisfaction with their work as the only reason for staying at home. This is how Kai talked about his situation: 'I was 
not at all satisfied with work then. I did not like my work then.' He continued, 'I was very happy to leave my work for a while.'

\section{Work and being a respectable citizen}

As previously discussed, mothers talked about their feelings of guilt. They felt guilty for staying at home as well as for leaving the child if they started to work. Kati said that, even as a child she was taught to respect work, and that she thought she had a duty to work, which made her feel guilty for not working. Kati gave a reason for feeling guilty when she said that she was well educated; she had a master's degree, so it was her duty to put her education to use. In Finland there are no tuition fees and you do not have to pay for education, thus Kati might even have felt that she had an obligation to the state. Maija expressed the same idea when she said that '.. when I have the education, it makes no sense not to use it.'

The first thing to come to Kati's mind when she was asked about the meaning of work was the word 'right.' She continued by talking about the importance of work. Even though she was not a man, there seemed to be in her talk about work the kind of idea as expressed by a Finnish saying: 'Work is the honour of man' [Työ miehen kunnia].

\section{Family finance}

The interviewees also discussed work and providing for the family. Several pointed out that money was not the most important issue when they were considering staying at home or working. Some of the families had saved money and used all possible support that could be received from the state. Families had also postponed big purchases. Maija, who planned to start working later, said that her salary would be needed when they bought a flat of their own.

Pekka also mentioned financial issues, which he believed played a role in the negotiations for most families. In his family, he said, money was not a decisive factor, 
because the spouses earned approximately the same income. However, Pekka saw providing for the family as a task related to 'manly honour'; although when he had said this he continued: 'Well, it is an idea of the past but deeply rooted in the thinking.'

An explanation often given as to men's lesser involvement in childcare and housework is that these tasks are a threat to their role as providers and to their masculine identities (see Bianchi \& Milkie, 2010). The interviewed fathers related to this. Pekka said that work is his 'manly honour', while Kai seemed to evade the question and talked about the importance of parents as role models of working parents, and in that sense that work was a duty. However, Kai did not think of work as an especially 'manly' duty; instead, he agreed that working was a shared responsibility.

In Teija's family, the answer to the question of who was responsible for providing for the family was very clear. When the interviewer asked about the provider's role, Teija answered with two words: 'Shared responsibility.'

\section{Work as social contact with other adults}

Teija's way of thinking about childcare and work was different from the thinking of the other three mothers, and in strong contrast with the ideology of intensive mothering. Throughout the interview she appeared very sure that work was the only thing in her life that mattered. She had been at home when the daughters were babies, but when she was asked if she thought she had learned something during that time, she replied, 'to arrange spoons, knives and forks in their proper places.'

Work was very important to Teija. She said that she 'could not live without her work.' When the interviewer asked her why, she said that, if she was at home all the time, her circles of everyday life would get smaller. Additionally, the social life in her workplace was very important to her. Money was not her reason for working; according to her, her wages were 
poor, but that she could not just stay at home. For Teija and her children, social life and contacts with other people were important and that daycare was better in that sense. Pete agreed with Teija to some extent when he talked about the lack of adult contacts while being at home. He said that he missed discussions with his colleagues at work during coffee and lunch breaks. However, he planned to be at home 'only for eight months, so it is really quite a short time.'

What you do at work is more appreciated than being at home

For Anna, working meant that what she did was appreciated in a different way than if she were at home, and that all this affected how she felt about herself. However, being equal with her husband was not important; however, when she was working she understood her working husband better. When she was working, she became familiar with both working life and home life.

Work as a way of life, part of identity, a project of one's own

Teija said that she could not live without her work, so work was a very important part of her life. However, work and childcare were separated in her thinking. Likewise, for Pekka, work was 'his way of life' and 'had a very profound meaning'. He continued:

Pekka: on the other hand it is it is something that I have grown into, it, it would be very difficult for me to describe myself without eh without eh referring to my profession

S: well yes do you think it is part of your identity then

Pekka: a very very very strong part

Thus, Pekka's work was a calling for him. During the interview, he also talked about childcare using military terms and pointed out that the birth of his child gave new meanings for his work. Pekka saw himself as the protector of the family which, in his thinking, included taking care of the child. For Maija, when she starts working, her work will be something of 
her own, 'her project,' and it will help her to see 'the line between work and leisure.' When she was a stay-at-home mother, she did not have time for herself, and the line between work and leisure became blurred, so that she felt she was 'working' all the time.

\section{Discussion}

In this study, meanings given to childcare and work by working parents and stay-at-home parents are explored. The aim is to shed light on what factors parents consider when they decide who is going to stay at home.

Belief in the idea of gender equality can be seen in the thinking of the interviewed parents. The decision who stays at home to take care of children was generally not based on gender. However, cultural beliefs in the primacy of the mother could also be seen. For instance, childcare for some of the fathers was an arena where they wished to show their abilities and even compete with the mother. Nevertheless, they did not hope to push the mother aside. Instead, they described the special relationship between the mother and the child. Moreover, the interviewed mothers said that staying at home with the child was not something they needed to make a 'conscious decision' about, whereas the fathers described the process of decision-making as 'employing their tactics.' Throughout the interviews the parents created an impression that staying at home to care for the children was more natural for mothers, while for fathers it was an exception. However, both mothers and fathers seemed to be aiming at finding a solution that would be good for both of them and the child.

Love for the child and a wish to be with him were talked about by both mothers and fathers. Thus homecare was seen as fulfilling both the needs of the parents and the child, but it was considered especially important for the wellbeing of the child. Several of the interviewees considered home as the best place for the child. For fathers, work, and especially the lack of time for spending with the child were in many cases factors pushing them home. Both mothers and fathers said that the birth of the child gave new meanings to their lives. 
When deciding how the childcare would be arranged, most spouses had discussed the issue with each other and also with significant others such as their parents, siblings, and friends. In these discussions, practical matters such as for whom it would be easier to stay at home, as well as differences in the personalities and needs of the spouses, were taken into consideration.

Being a stay-at-home parent is temporary for both mothers and fathers and, in the Finnish context, both parents intended to work at some point in their life and be providers for the family. Moreover, the line between what was considered 'work' and what was considered 'care' was blurred in the thoughts of the interviewed parents. Work was seen as important for both mothers and fathers. At work, parents were able to have social contacts with other adults, and some mothers felt that what they did at work was more appreciated than what they did at home. The expectations of good mothering contradicted the ones related to the idea of a good working citizen and made some of the mothers felt guilty.

To sum up, the versatile meanings given to care and work play an important role when parents decide either to work or to stay at home. Moreover, the decision making seems be affected by the personality of each parent, cultural beliefs of good parenting including gender beliefs as well as factors related to very practical and everyday issues such as for whom staying at home is easier to organize.

The findings provide insight into the decision-making on work-care issues in families in Finland. However, due to the small-scale exploratory nature of the study, there are several limitations. Although the subjects in this study maintained that family finance was not a decisive factor when deciding who stayed at home, the mothers in the families in which the father stayed at home were probably better paid than the fathers. Thus, the loss of income was smaller than in families where the father earned more than the mother. Moreover, none of the parents considered themselves as career persons, so it is very likely that an interview with 
parents who focus more on their career would give different results. Likewise, the views of the fathers who would not stay at home are lacking.

The fathers of this study had acted differently from the majority of fathers because they had chosen to be stay-at-home fathers. Thus, it is likely that the decision-making in these families required more negotiations and discussions than in the majority of Finnish families. Nevertheless, it is evident that, because the decision as to how childcare is to be organized is, in most cases, the result of various negotiations and discussions within the families, in future studies data from both spouses are needed. However, one of the mothers (Teija) in the study maintained firmly that the decision was not discussed with anyone, and that she made the decision on her own. 


\section{References}

Bianchi, S. M., \& Milkie, M. A. (2010). Work and family research in the first decade of the $21^{\text {st }}$ century. Journal of Marriage and Family, 72, 705-725. doi:10.1111/j.17413737.2010.00726.x

Bowlby, S., McKie, L., Gregory, S., \& MacPherson, I. (2010). Interdependency and care over the lifecourse. London: Routledge.

Braun, V., \& Clarke, V. (2006). Using thematic analysis in psychology. Qualitative Research in Psychology, 3, 77-101. doi:http://dx.doi.org/10.1191/1478088706qp063oa

Ciccia, R., \& Bleijenbergh, I. (2014). After the male breadwinner model?: Childcare services and the division of labor in European countries. Social Politics: International Studies in Gender, State and Society, 21, 50-79. doi:10.1093/sp/jxu002

Doucet, A. (2006). Do men mother? Fathering, care, and domestic responsibility. Toronto: University of Toronto Press.

Eby, L. T., Casper, W. J., Lockwood, A., Bordeaux, C., \& Brinley, A. (2005). Work and family research in IO/OB: Content analysis and review of the literature (1980-2002). Journal of Vocational Behavior, 66, 124-197. doi:

http://dx.doi.org.ezproxy.jyu.fi/10.1016/j.jvb.2003.11.003

Ellingsæter, A. L., \& Leira, A. (2006). Epilogue: Scandinavian policies of parenthood - a success story? In A. L. Ellingsæter, \& A. Leira (Eds.), Politicising parenthood in Scandinavia. Gender relations in welfare states (pp. 265-277). Bristol, UK: Policy Press.

Ferguson, M., Carlson, D., Hunter, E. M., \& Whitten, D. (2012). A two-study examination of work-family conflict, production deviance and gender. Journal of Vocational Behavior,81, 245-258.doi: http://dx.doi.org/10.1016/j.jvb.2012.07.004 
Forsberg, H., \& Strandell, H. (2007). After-school hours and the meanings of home: Redefining Finnish childhood space. Children's Geographies, 5, 393-408. doi:10.1080/14733280701631841

Gibson, W. J., \& Brown, A. (2009). Working with qualitative data. London: SAGE.

Greenhaus, J. H., \& Beutell, N. J. (1985). Sources of conflict between work and family role. Academy of Management Review, 10, 76-88. doi:10.5465/AMR.1985.4277352

Greenhaus, J. H., \& Powell, G. N. (2006). When work and family are allies: A theory of work-family enrichment. Academy of Management Review, 31, 72-92. doi :10.5465/AMR.2006.19379625

Gubrium, J. and Holstein, J. A. (1990). What is family? California: Mountain View.

Guendouzi, J. (2006). “The guilt thing': Balancing domestic and professional roles. Journal of Marriage and Family, 68, 901-909. doi:10.1111/j.1741-3737.2006.00303.x

Guest, D. E. (2002). Perspectives on the study of work-life balance. Social Science Information, 42, 255-279. doi:10.1177/0539018402041002005

Haataja, A., \& Nyberg, A. (2006). Diverging paths? The dual-earner/dual-carer model in Finland and Sweden in the 1990s. In A. L. Ellingsæter, \& A. Leira (Eds.), Politicising parenthood in Scandinavia. Gender relations in welfare states (pp. 217-239). Bristol, UK: Policy Press.

Harkness, S. and Super, C.M. (1996). Introduction. In S. Harkness and C. M. Super (Eds.) Parents' cultural belief systems. Their origins, expressions, and consequences. New York: Guilford Press, 1-26.

Hays, S. (1996). The cultural contradictions of motherhood. New Haven, CT: Yale University Press.

Hobson, B., \& Fahlén, B. (2009). Competing scenarios for European fathers: Applying Sen’s capabilities and agency framework to work-family balance. The Annals of the American Academy of Political and Social Science, 624, 214-233. doi:10.1177/0002716209334435 
Hochschild, A. R. (2001). The time bind: When work becomes home and home becomes work. New York: Henry Holt.

Johansson, T., \& Klinth, R. (2007). Caring fathers: The ideology of gender equality and masculine positions. Men and Masculinities, 11, 42-62. doi:10.1177/1097184X06291899

Lammi-Taskula, J. (2007). Parental leave for fathers? Gendered conceptions and practices in families with young children in Finland. Stakes, Research Report 166, Helsinki.

Lynch, K. (2007). Love labour as a distinct and non-commodifiable form of care labour. The Sociological Review, 55(3), 550-570. doi:10.1111/j.1467-954X.2007.00714.X

Mahon, R., Anttonen, A., Bergqvist, C., Brennan, D., \& Hobson, B. (2012). Convergent care regimes? Childcare arrangements in Australia, Canada, Finland and Sweden. Journal of European Social Policy, 22, 419-431. doi:10.1177/0958928712449776

Milkie, M. A., Bianchi, S. M., Mattingly, M. J., \& Robinson, J. P. (2002). Gendered division of childrearing: Ideals, realities, and the relationship to parental well-being. Sex Roles, 47, 21-38. doi:10.1023/A:1020627602889

Moss, P., \& Brannen, J. (2003). Concepts, relationships and policies. In J. Brannen, \& P. Moss (Eds.), Rethinking children's care (pp. 1-22). Buckingham, UK: Open University Press.

Nätkin, R. (1997). Kamppailu suomalaisesta äitiydestä. Maternalismi, väestöpolitiikka ja naisten kertomukset. [The struggle over Finnish motherhood. Maternalism, population politics and women's stories]. Helsinki, Finland: Gaudeamus.

Närvi, J. (2012). Negotiating care and career within institutional constraints - work insecurity and gendered ideals of parenthood in Finland. Community, Work \& Family, 15, 451-470. doi: http://dx.doi.org/10.1080/13668803.2012.724827 
Perälä-Littunen, S. (2007). Gender equality or primacy of the mother? Ambivalent descriptions of good parents. Journal of Marriage and Family, 69, 341-351. doi:10.1111/j.1741-3737.2007.00369.x

Rosso, B. D., Dekas, K. H., \& Wrzesniewski, A. (2010). On the meaning of work: A theoretical integration and review. Research in Organizational Behavior, 30, 91-127. doi:10.1016/j.riob.2010.09.001

Salmi, M., Lammi-Taskula, J., \& Närvi, J. (2009). Perhevapaat ja työelämän tasa-arvo [Family leaves and equality in working life]. Publication of the Ministry of Employment and The Economy, 24/2009, Helsinki.

Saraceno, C. (2008). Gender and care. Old solutions, new development? The Ursula Hirschmann Annual Lecture on Gender and Europe. RSCAS Distinguished Lecture 2008/02. San Domenica di Fiesole: European University Institute.

Sümer, S. (2009). European gender regimes and policies. Comparative perspectives. Farnham, UK: Ashgate.

Super, D. E., \& Šverko, B. (Eds.). (1995). Life roles, values, and careers: International findings of the Work Importance Study. San Francisco, CA: Jossey-Bass.

Westring, A. F., \& Ryan, A. M. (2011). Anticipated work-family conflict: A construct investigation. Journal of Vocational Behavior, 79, 596-610. doi:10.1016/j.jvb.2011.02.004

Wrzesniewski, A., \& Dutton, J. E. (2001). Crafting a job: Revisioning employees as active crafters of their work. Academy of Management Review, 26, 179-201.

doi:10.5465/AMR.2001.4378011 